AGENDA : Analisis Gender dan Agama , Vol. 3 (1), 2021, (Juni)

\title{
MARRIAGE SATISFACTION ON A COUPLE OF TUNGGU TUBANG IN THE SEMENDE TRADITION OF SOUTH SUMATRA
}

\author{
Yusafrida Rasyidin \\ UIN Raden Intan Lampung \\ Email : \\ yusafridarasyidin@radenintan.ac.id
}

\section{Annisa Fitriani}

UIN Raden Intan Lampung

Email :

Annisa.fitriani@radenintan.ac.id

\begin{abstract}
The purpose of this research is to find out how marriage satisfaction is to know what are the factors that influence marriage satisfaction in the waiting couple tubang in the traditional traditions of Semende, South Sumatra. This research uses a qualitative approach with a case study method, the data analysis technique used is thematic analysis by coding the results of the interview transcripts that have been made verbatim. The results showed that effective communication and cooperation play a role in marital satisfaction, effective communication can solve problems related to finance, family, parenting and sex. Whereas role cooperation in the family is an absolute requirement for family function and the openness of the couple to recognize and solve problems that arise to get the best solution.
\end{abstract}

Keywords : Marriage Satisfaction, TungguTubang, Adat Semende

\section{PENDAHULUAN:}

Setiap individu yang memasuki kehidupan pernikahan akan membawa kebutuhan, harapan, serta keinginannya masing masing. Suami maupun istri akan mendambakan kehidupan pernikahan yang bahagia dan puas serta berharap dapat memenuhinya dalam institusi pernikahan (Nihayah, Adriani \& Wahyuni, 2013). Pada kenyataannya tidak semua pasangan dapat mencapai kepuasan dalam pernikahan. Penelitian yang dilakukan oleh Afni dan Indrijati (2011) menjelaskan bahwa dua dari tiga subjek merasakan ketidakpuasan pernikahan karena tidak terpenuhinya aspek material, seksual, dan psikologis dalam rumah tangga. Selain itu, Glenn (dalam Halford, Lizzio, Wilson \& Occhipinti, 2007) dalam penelitiannya mengatakan bahwa kepuasan dalam hubungan pada pasangan suami istri umumnya meningkat saat pernikahan, akan tetapi hal tersebut akan menurun dan sekitar 3-4 persen terjadi perceraian pada saat pernikahan memasuki usia 10 tahun.

Kepuasan pernikahan ini tergantung atas kebutuhan individu, harapan, dan dari hubungan yang dijalaninya. Sebenarnya, konsep ini hampir sama dengan definisi 
kebahagiaan pernikahan karena hanya individu yang menjalaninya yang mampu mengatakan bagaimana kebahagiaan atau kepuasan mereka (Muslimah, 2010). Menurut Hawkins (Srisusanti, 2013) kepuasan perkawinan merupakan perasaan subjektif akan kebahagiaan dan pengalaman menyenangkan yang dialami oleh suami dan isteri dalam perkawinan dengan mempertimbangkan keseluruhan aspek perkawinan dikarenakan sebuah perkawinan dapat dikatakan mencapai kepuasan bila satu pihak dapat sepenuhnya menerima pasangannya dan kepuasan itu dirasakan dari waktu ke waktu (Bowman \& Spanier dalam Srisusanti, 2013).

Adapun aspek-aspek yang dievaluasi oleh pasangan suami isteri untuk menentukan kepuasan perkawinan ialah kemampuan sosial suami isteri (marriage sociability), persahabatan dalam pernikahan, masalah ekonomi (economic affair), kekuatan perkawinan (marriage power), hubungan dengan keluarga besar, persamaan ideologi (ideological congruence), keintiman, dan taktik interaksi (Clayton dalam Hidayah, 2006). Aspek aspek tersebut tidak lepas dengan yang namanya budaya, karena dalam setiap aspek pernikahan budaya selalu menjadi kontribusi utama. Banyaknya suku bangsa dengan adat istiadat yang berbeda-beda menjadikan Indonesia Khususnya Pulau Sumatera wilayah yang majemuk (plural), terdiri dari berbagai suku bangsa atau masyarakat yang beraneka ragam. Salah satu suku yang ada di Sumatera adalah Suku Semende. Suku Semende adalah salah satu suku di Sumatera Selatan yang sebagian besar berdomisili di Kabupaten Muara Enim, tepatnya di Kecamatan Semende Darat Laut, Semende Darat Tengah, Semende Darat Ulu, dan sebagian lainnya berada di Kota Prabumulih, Kabupaten Ogan Komering Ilir, dan Kabupaten Ogan Komering Ulu. (Praditama M.R, 2013) Selain di wilayah tersebut, Suku Semende juga menyebar ke wilayah lainnya di Sumatera. Salah satu daerah penyebaran Suku Semende adalah Kecamatan Bukit Kemuning Kabupaten Lampung Barat. Suku Semende dikenal sebagai suku yang memegang teguh adat. Suku Semende memiliki beragam adat yang khas seperti bahasa, kesenian, upacara perkawinan, dan sistem pewarisan. Diantara berbagai macam adat Semende yang masih dipakai dan dijunjung tinggi oleh masyarakat Semende sampai saat ini adalah budaya tunggu tubang.

Tunggu tubang adalah sistem pewarisan dalam masyarakat Semende. Sistem pewarisan ini merupakan sistem pewarisan mayorat perempuan, dimana anak tertua perempuan sebagai penunggu harta orang tua, yang berperan sebagai pemimpin keluarga menggantikan kedudukan ayah atau ibu. Anak perempuan tertua diserahi suatu jabatan dan dibekali dengan harta keluarga yang berupa kebun atau sawah sebagai sumber mata pencarian dan sebuah rumah sebagai tempat tinggal. Kedua harta ini tidak boleh dijual oleh tunggu tubang karena harta yang dimiliki oleh tunggu tubang merupakan harta milik bersama dalam keluarga dan sebagai tempat berhimpun atau bermusyawarah anggota keluarga. (Iskandar, 2003)

Maka dari itu menjadi seorang tunggu tubang merupakan sebuah tugas yang berat, karena seorang tunggu tubang memiliki peranan untuk 
mempertahankan keutuhan harta pusaka keluarga dan harus mampu menjaga keutuhan keluarga dari berbagai konflik khususnya konflik perebutan harta waris sehingga dalam keluarga tercipta keamanan, ketentraman, dan kesejahteraan. Orang yang berhak menduduki posisi sebagai tunggu tubang adalah anak perempuan yang tertua, apabila tidak ada anak perempuan, maka tunggu tubang dipilih secara mufakat oleh seluruh keluarga salah seorang anak yang ada untuk menjadi tunggu tubang dan apabila terjadi anak tunggal otomatis menjadi tunggu tubang. Seorang tunggu tubang menjalankan fungsinya baik ketika orang tuanya masih hidup atau pun sudah meninggal dengan syarat ia menikah dan harus tetap tinggal di rumah orang tuanya, apabila ia keluar dari rumah orang tuanya maka ia tidak berhak lagi menjadi tunggu tubang. (Hasil wawancara dengan Bapak Arimbi Warga Kecamatan Bukit Kemuningi, tanggal 10 Juni 2019).

Melalui penelitian pendahuluan pada tanggal 10 Juni 2019, di KecamatanBukit Kemuning Kabupaten Lampung Utara ditemukan fakta yang berbeda. Pada tahun 2019 sebanyak 124 orang tunggu tubang masih menjalankan perannya. Data jumlah tunggu tubang (124 orang) tersebut diperoleh dari 30\% jumlah Kepala Keluarga (KK) yang ada di Bukit Kemuningi yang merupakan masyarakat bersuku semende. Setiap KK memiliki tunggu tubang yang harus menetap di rumah yang berada di Kecamatan Bukit Kemuning Kabupaten Lampung Barat. Dalam tradisi tunggu tubang, istri selain menjalankan perannya dalam mengurus keluarganya sehari-hari. Juga berperan nyata dalam dalam pengambilan keputusan dan kegiatan produktif lainnya terkait dengan warisan. Ini dikarenakan adanya suatu tatanan atau sistem yang memungkinkan hal itu terjadi dan berlangsung turun menurun. Dalam pernikahan tidak hanya melibatkan dua pihak antara seorang perempuan dan seorang laki-laki, akan tetapi juga melibatkan kedua keluarga. Perkawinan biasanya dikatakan sebagai penyatuan dua individu, tetapi kenyataannya merupakan penyatuan dua keluarga. seharusnya dalam pernikahan itu memiliki sikap pandangan hidup yang sama dan interaksi komunikasi yang baik dengan pasangan maupun keluarga, akan tetapi hal ini sering menjadi kendala dalam pasangan tunggu tubang. Sehingga dapat menimbulkan konflik dalam sebuah hubungan pernikahan karena terjadi perbedaan antara harapan sebelum menikah dan kenyataan setelah menikah. (Setiawan \& Roby, 2013)

Pada kebanyakan suku di Indonesia, dalam kehidupan perkawinannya suami memiliki otoritas lebih dari pada istri. Tetapi ada juga tradisi adat dimana istri lebih banyak memegang otoritas daripada suami, seperti tradisi adat suku Semende Sumatera Selatan. Tunggu Tubang merupakan derajat yang diberikan secara turun menurun terhadap anak perempuan tertua dalam keluarga suku Semende. Anak perempuan tertua yang mendapat derajat Tunggu Tubang diberi mandate menunggu, menggunakan, mengatur hasil dan harta peninggalan orang tua. Tradisi budaya inilah yang kemudian menjadi latar belakang mengapa dalam adat tunggu tubang suku semende, istri menjadi lebih dominan dalam 
pengaturan rumah tangga daipada suami. Berdasarkan permasalahan tersebut maka tujuan penelitian ini adalah mengetahui bagaimana gambaran kepuasan perkawinan dan faktor- faktor apa saja yang mempengaruhi kepuasan pernkahan pada pasangan tunggu tubang dalam tradisi adat Semende Sumatra Selatan

Penelitian ini menggunakan metode penelitian kualitatif yang dilakukan pada sepasang suami istri yang, dengan usia perkawinan minimal 5 tahun, tinggal secara mandiri, memiliki anak minimal 1. Teknik analisis data yang digunakan dalam penelitian ini adalah analisis tematik dengan melakukan koding terhadap hasil transkrip wawancara yang telah dibuat verbatim.

Subjek penelitian ini memiliki kriteria (1) suami istri tidak tinggal terpisah dan istri diberikan tanggung jawab sebagai Tunggu tubing (2) bersuku Semende asli yang bertempat tinggal di Kecamatan Bukit Kemuning, Lampung Utara, (3) menerapkan tradisi Tunggu Tubang dalam kehidupan sehari-hari, dan (4) memahami kebijakan, aturan, hak, dan kewajiban sebagai pewaris Tunggu Tubang.

\section{HASIL DAN PEMBAHASAN:}

\section{A. Subyek AB dan MB \\ Komunikasi dalam Keluarga}

Pola komunikasi yang terjalin pada pasangan $\mathrm{AB}$ dan $\mathrm{MB}$ adalah komunikasi timbal balik. Kedua belah pihak merasa mempunyai kewajiban dan peran untuk dapat berkomunikasi dengan baik kepada pasangan. Suami (AB) yang mendapatkan beban lebih seperti harus menjaga adik adik dari istri (MB), merasa harus dapat berkomunikasi dengan efektif dan responsif dikarenakan seringnya muncul permasalahan kecil.

Komunikasi yang baik dan nyaman menurut pasangan $\mathrm{AB}$ dan $\mathrm{MB}$ adalah masing masing (suami istri) mempunyai pilihan setiap kali berinteraksi dengan anak, pasangan, orang tua, mertua maupun anggota keluarga lainnya, $\mathrm{AB}$ dan $\mathrm{MB}$ harus membiasakan memilih bagaimana cara berkomunikasi yang baik. Terlebih jika komunikasi yang muncul berupa respon yang cukup emosional maka menurut pasangan $\mathrm{AB}$ dan $\mathrm{MB}$ adalah bagaimana untuk dapat mendengarkan keluh kesah pasangan dengan baik. (suranto, 2011). (AB) mengatakan bahwa jika komunikasi pasangan sangat membosankan atau tidak peduli, maka tidak menutup kemungkinan suasana rumah akan menjadi tegang, konflik dan saling curiga. Hal tersebut disampaikan oleh suami (AB) "ya kita sama orang lain aja bisa ngobrol asik, masak sama pasangan sendiri ngebosenin. Komunikasi yang begini yang sering memicu konflik"

Maka kesimpulan yang dapat diambil dari komunikasi menurut pasangan $\mathrm{AB}$ dan $\mathrm{MB}$ adalah jika kedua belah pihak dapat membiasakan berkomunikasi dengan baik kepada siapapun khususnya kepada pasangan maka pasangan akan memiliki kenyamanan dalam berkomunikasi.

\section{Pemecahan Masalah dalam Keluarga \\ Dalam hal pemecahan masalah dalam keluarga Keterbukaan adalah kunci awal yang efektif untuk menghadapi tantangan dan memecahkan persoalan dalam} kehidupan berumah tangga (Gainau, 2009) hendaknya suami dan isteri saling terbuka dan menyampaikan 
perasaan serta keinginan dirinya secara luas. Istri (MB) sering merasa tidak enak kepada suami (AB) dikarenakan memberi tanggungan lebih seperti harus memenuhi kebutuhan adik adik dari istri (AB) namun hal tersebut sering dibantah oleh suami (AB). Suami (AB) mengatakan bahwa sebelum menikahi istrinya. (AB) sudah paham akan kewajiban istri (MB) sebagai tunggu tubang. Keterbukaan inilah yang menjadi kunci ketika muncul persoalan persoalan rumah tangga. Istri pun (MB) mengakui proses saling mengenal pada saat awal pernikahan akan membentuk bagaiamana keterbukaan pada pasangan. " untungnya istri saya ini orangnya pencerita segala macam diceritain. Jadi kita tidak ada yang ditutup tutupi"

Selain kepada suaminya (AB) istri (MB) juga sangat terbuka terhadap anak anak dan adik adiknya. Biasanya mereka mengobrol ketika sedang menonton TV, makan malam dan berpergian. Istri mengungkapkan bahwa harus membiasakan diri berkomunikasi dengan keterbukaan dan kelapangan hati " saya itu paling ga suka. Kalau anak anak dan adik adik saya pulang kerumah langsung masuk kamar, pasti saya suruh keluar ngobrol ngobrol dulu.. kayak gini kan bikin hubungan semakin dekat"

\section{Keputusan Permasalahan Keuangan}

Dalam memberikan keputusan terkait permasalahan keuangan Istri (MB) harus menjaga ke 2 adiknya sebelum adik adiknya berumah tangga. (karena orang tua MB sudah meninggal) Sehingga keperluan adik adik MB dipegang secara penuh oleh $\mathrm{AB}$ dan $\mathrm{MB}$. Hal tersebut terkadang membuat $\mathrm{AB}$ dan $\mathrm{MB}$ harus mengambil keputusan financial secara bersama sama. walaupun dari ungkapan istri (MB) keputusan keuangan kadang kala diserahkan sepenuhnya kepada suami (AB). "kalau adik adik saya ada keperluan, saya minta masukan dulu dari bapak. Kalau kata bapak oke ya jalan"

Dalam mengelola keuangan rumah tangga tentu harus memperhitungkan banyak faktor seperti dana pendidikan anak, asuransi kesehatan, dana investasi, tabungan hari tua, dan lainlain (Iskandar dkk, 2010) Terlebih istri (AB) masih harus menanggung kedua adiknya. Maka disini istri lebih komunikatif terhadap suami (AB) dalam persoalan keuangan. "Saya mah ga takut, kalau mau minta apa apa sama bapak. Alhamdulillah bapak juga ngeresponnya baik".

Keuangan rumah tangga hanya dapat terealisasi dengan baik apabila pasangan dapat mengkomunikasikan apa yang menjadi kebutuhan pokok dan mana yang bukan kebutuhan (suranto, 2011).Suami (AB) yang bekerja sebagai Guru harus dapat mengelola keuangan dengan baik dan harus bersikap responsif terhadap kebutuhan keluarganya. Istri (MB) yang menjadi tunggu tubang keluarga dan mendapatkan beberapa harta warisan dari orang tua seperti, rumah, tanah dan kontrakan. Harus dapat mengelola harta warisan tersebut baik. Membagi kebutuhan dengan adil terhadap anak dan adik adiknya. "Sayang kalau engga mampu ngolahnya. Tapi , pengelolaan warisan bergantung juga keputusan keluarga agar bisa dialokasikan untuk masa depan"

Begitu pula saat istri (AB) menyampaikan keinginan atau kebutuhan tetapi kadang tidak mendapatkan respon baik oleh suami 
(AB) maka hal -hal yang istri (AB) lakukan adalah untuk tidak bersikap emosi, menuduh dan menyalahkan pasangan. " awal awal nikah kalau aku mau beli sesuatu dilarang larang sama bapak aku kesel, marah.. tapi udh semakin kesini ya biasa aja, malah nyoba untuk ga emosian. Hehehe" kesimpulan dalam pengambilan keputusan terkait permasalahan keuangan yaitu mengawali dengan pembicaraan ringan jangan membuat tidak nyaman. Dengan cara ini, kedua belah pihak akan sama-sama merasa nyaman dan mudah untuk mengurai persoalan. (Yoanita, 2009)

\section{Pola Asuh Anak}

Dalam pola asuh anak Pasangan $\mathrm{AB}$ dan $\mathrm{MB}$ mempunyai 2 anak yang sekolah ditingkat dasar dan menengah. Pola asuh yang diterapkan oleh pasangan $\mathrm{AB}$ dan $\mathrm{MB}$ kepada anaknya dan adiknya sama. Tidak ada perbedaan dan pengecualiaan karena MB dan istri (MB) paham sekali bagaimana pengasuhan orang tuanya dulu kepada anak anaknya dan juga paman dan bibinya. Disinilah terjadi role model pengasuhan anak pada orang tua. Setiap orang tua tentunya ingin yang terbaik bagi anak-anak mereka. Keinginan ini kemudian akan membentuk pola asuh yang akan ditanamkan orangtua kepada anakanak. Dan Masing-masing orangtua tentu berhak memutuskan pola asuh yang tepat untuk anak mereka. Baik itu pola asuh yang permisif, otoriter, atau autoritatif, bisa dipilih untuk mendidik dan membesarkan anak. (Zulkifli, 2009). Pada pasangan ini pola asuh yang terapkan adalah pola asuh permisif sehingga pola asuh anak jenis ini memberikan kebebasan pada anak untuk menyatakan dorongan atau keinginannya. Pola asuh ini tidak memberikan batasan yang tegas pada anak. Biasanya orangtua akan mengikuti apapun yang anak inginkan sehingga cenderung tidak memiliki keteraturan dan kemampuan untuk meregulasi diri.(djamarah dkk, 2004)

\section{B. Subyek DS dan SB Kesamaan Peran dalam Keluarga}

Pasangan DS dan SB adalah pasangan yang sama sama ingin berkerja dibidangnya masing masing. DS bekerja sebagai wiraswasta dan SD bekerja sebagai perawat di Puskesmas. Keduanya memang telah sepakat untuk sama sama dalam mencari nafkah. Bahkan dalam peran domestik yaitu yang berkaitan dengan urusan memasak, menyiapkan makanan, mencuci pakaian, dan pengasuhan anak DS dan SB sepakat untuk melakukan bersama Menurut suami (DS) Kerjasama peran dalam keluarga merupakan syarat mutlak awal terrjadinya pelaksanaan fungsi keluarga. Tugas keluarga akan terasa ringan apabila dikerjakan dengan tulus dan ikhlas disertai dengan perencanaan bersama antara suami-istri. (Lestari, 2012) "saya mendukung sekali pekerjaan istri, sebelum menikah dengan saya dia juga sudah bekerja, sudah pinter cari uang sendiri".

Disini DS dan SB berperan penuh untuk dapat berfungsi secara optimal dalam keluarga karena menurut DS istrinya pun bekerja untuk dapat memenuhi kebetuhan keluarga. "kalau saya lembur di Puskesmas, alhmadulilah suami mau gantian urusin rumah. Kan kalau bapak jam kerja lebih fleksibel jaga toko sendiri”

Istri (SB) yang statusnya sebagai tunggu tubang dan mendapatkan 
kepercayaan untuk mengelola harta warisan keluarga serta bekerja sebagai Perawat Tetap di sebuah Puskesmas sering kali membuat suami (DS) merasa malu dikarenakan kondisi ekonomi dimana seharusnya suami yang memegang peranan dalam membiayai dan menafkahi semua keperluan rumah tangga, tetapi kemudian diambil porsi terbesarnya oleh isteri. Hal ini sempat membuat suami (DS)merasa tidak percaya diri.

\section{Berbagi dengan Keluarga}

Istri yang memiliki posisi sebagai tunggu tubang berkewajiban penuh untuk dapat menolong sanak keluarga jika mengalami kesulitan, dalam hal ini istri (SB) memiliki 3 adik yang sudah berkeluarga sehingga tinggal bersama keluarga masing masing, namun tak jarang adik adiknya masih sering meminta bantuan secara finansial. Hal ini ditanggapi positif oleh istri (SB) karena prinsip hidup istri (SB) adalah Keluarga adalah segalanya. tempat untuk berkeluh kesah dan membagikan cerita. Maka istri (SB) akan sangat senang ketika didatangi oleh keluarga atau adik adiknya. SB pun membuat sebuah arisan kecil kecil an dengan tujuan bisa berkumpul setiap bulannya. Kegiatan dan urusan masing-masing menjadikan tidak pernah bertemu dalam jangka waktu lama. " saya sengaja bener loh bikin arisan keluarga biar bisa kumpul semua, kalau ga digituin yang dari lampung tengah, lampung barat, karang jarang banget pulang"

Menurut DS dan SB Tradisi berkumpul dan menghabiskan waktu bersama keluarga dengan melakukan kegiatan seperti arisan atau makan bersama akan menghasilkan hubungan yang kuat antar anggota keluarga.
Inilah momen tepat untuk berkumpul dan bercerita, karena hal ini akan menimulkan perasaan saling memiliki, keamanan, dan kenyamanan di dalam keluarga.

\section{Pemecahan Masalah dalam Keluarga}

Tradisi pola asuh sejak kecil dari kedua pihak yang mungkin sudah tertanam masing-masing dan akhirnya menjadi kepribadian kedua pasangan. Hal ini nyatanya sangat berpengaruh saat pasangan dihadapkan dalam menyelesaikan masalah . Contoh, perbedaan karakter dan pola asuh dari masing-masing keluarga pasangan akan bertentangan ketika mengurus anak. seperti, istri (SB) terbiasa diasuh dan dididik secara keras oleh orangtuanya, dan suami (DS) terbiasa diajarkan hidup santai tanpa adanya banyak aturan. ketika mereka berdua disatukan dalam rumah tangga pola asuh mana yang harus diterapkan ke anak nantinya? "kalau istri sama anak cenderung keras, kalau saya biasa aja. Ini sih yang suka jadi bikin berantem ibu dan ayahnya belum lagi kalau sudah membicarakan masalah keuangan, bisa jadi lebih sensitif.

Biasanya, masalah berkutat di antara siapa yang harus bekerja dan siapa yang rela/harus tinggal di rumah, siapa yang pendapatannya lebih tinggi, siapa yang mengurus keuangan rumah tangga, dan berapa yang harus disisihkan untuk keperluan harian. Dalam meminimalisir hal tersebut maka DS dan SB sepakat harus fleksibel dan transparan mengenai kondisi keuangan masingmasing."kami sudah sepakat hal hal yang bisa bikin konflik terutama soal keuangan, harus dibicarakan secara terbuka" cara terpenting untuk 
membangun kepercayaan bersama pasangan menurut DS dan SB adalah dengan saling jujur dan terbuka saling menerima kelebihan juga kekurangan satu sama lain.

\section{Komunikasi}

Komunikasi keluarga memiliki banyak aspek sebagai unsur pembentuk terciptanya relasi harmonis bagi semua peserta komunikasi yang terlibat di dalamnya. Tidak dapat disangkal, hampir sebagian besar kegiatan manusia berkaitan dengan komunikasi, baik verbal maupun non-verbal. Pada pasangan ini .Komunikasi yang lebih di dominasi oleh istri (SB). Hal ini terbukti dari ungkapan suami (DS) "istri kalau sudah ngomong A ya harus A, ga bisa diubah. Contohnya anak harus masuk pesantren". Komunikasi yang terjalin pada pasangan ini adalah komunikasi satu arah, pesan yang disampaikan oleh istri (SB) yang mana suami (DS) tidak memiliki kesempatan untuk bertanya atau memberikan umpan balik. "saya ya mba.. kadang kadang kalau cerita sama ayah ini cuma ngangguk ngangguk aja”.

Padahal pasangan sudah paham bahwa komunikasi yang terjalin tidak sehat, tetap suami (DS) lebih memaklumi karena istri (SB) merupakan anak tertua dan memiliki pola asuh yang cenderung otoriter. Dalam hal ini Kekurangan komunikasi satu arah banyak sekali memiliki kekurangan, ini dikarenakan tidak adanya untuk umpan balik yang dilakukan setelah pemberian informasi tersebut, dimana ini bisa mengakibatkan dampak negatif dari penggunaan komunikasi satu arah ini. Suami dan istri tidak dapat menjalin komunikasi yang berkesinambungan melalui media yang sama, artinya hanya dari satu pihak saja, pihak lain hanya mendengarkan.

\section{Subyek AS Mengatasi Konflik dalam Keluarga (Pemecahan Masalah)}

Dalam membina keluarga, setiap keluarga menginginkan keluarga yang sakinah, yang mampu memberikan cinta dan kasih sayang pada anggota keluarganya, sehingga mereka memiliki rasa aman, tenteram, damai dan bahagia dalam mengusaha kan tercapainya kesejahteraan hidup dunia dan akhirat. Kesimpulan dari pertanyaan peniliti terkait keluarga . Namun kadang kala masih sering terjadi konflik keluarga yang membutuhkan solusi atau pemecahan masalah. Menurut AS Dengan keterbukaan, bisa menyingkat masa pengenalan anda dalam waktu yang lebih cepat dibandingkan dengan apabila tidak bersikap terbuka. Tentu saja pengenalan yang diperlukan antara suami isteri tidak terbatas pada hal-hal yang bersifat permukaan saja, diperlukan pengenalan yang mendalam dan tuntas. "pokoknya saling terbuka aja, apalagi kalau ada masalah ya solusinya harus banyak ngobrol".

Menurut AS, dalam kehidupan keseharian, masing-masing bisa mengungkapkan keinginan hati dan perasaan tanpa ada ketakutan dan hambatan. Masing-masing menyampaikan kisah diri dan nasihat kepada pasangannya. Dan juga suami istri perlu terbuka mengutarakan halhal yang disukai dan tidak sukai, keinginan dan harapan yang diberikan kepada pasangan. perlu terbuka untuk menyampaikan keinginan masing masing, sampai kepada masalahmasalah yang teknis, hal hal tersebut merupakan kiat kiat pada pasangan 
s"saya dan istri sangat terbuka, tujuannya sih biar ga saling curiga, jadi hal hal kecil dibicarakan"

\section{Berbagi dengan Keluarga (Aktifitas Bersama)}

AS mengungkapkan bahwa status istri yang menjadi tunggu tubang dalam keluarga, bisa membagi perhatian kepada keluarganya dan keluarga suami. AS sebagai suami juga tidak melarang ketika istri sering mengajak keluarganya untuk berlibur. AS dan istri memiliki 3 anak dan 2 adik. Sehingga menurut AS, istri ketika pulang kerumah orang tua bukan disebut sebagai pulang kampung tetapi pulang ke rumah sendiri. "istri saya pulang ke bukit kemuning itu gam au disebut pulang kampung, malah dia nganggep kalau disini (tanjung karang) dia sedang merantau".

AS sangat memahami kondisi istri yang harus bisa berbagi waktu dan perhatian dengan keluarga. Sejauh ini hubungan AS dan keluarga istri sangat baik. AS selalu menemani istri untuk pulang ke Bukit Kemuning dan kadang kadang mengajak keponakan dari adik adik istri untuk berlibur ke tanjung karang. "kalau pulang ke bukit kemuning saya sering ngajak keponakan keponakan maen ke karang. Mereka seneng banget"

\section{Manajemen Keuangan}

Menerapkan manajemen keuangan keluarga tak hanya mengalokasikan dana yang ada untuk memenuhi kebutuhan keluarga. namun perlu membuat skala prioritas terhadap barang yang ingin dibelinya. Suami yang bekerja sebagai PNS PEMKOT harus dapat mengelola keuangan dan membuat perencanaan jangka panjang. "Alhamdulillah sampai saat ini kebutuhan keluarga masih tercukupi, enaknya jadi PNS ya gini ada yang ditunggu di awal bulan". Suami mengakui terkait pengelolaan keuangan masih harus "berembuk" dengan istri. Istri yang juga mempunyai warisan tunggu tubang dari keluarga berupa kebun yang hasilnya dapat dipanen 3 bulan sekali, seringkali menanyakan pada suami bagaiamana pembagian kepada adik adiknya. "istri itu ada kebon luas dikampung, kalau panen dia juga juga suka nanya. Dibagi kesiapa saja?

Selain itu suami (AS) juga menjelaskan tidak ada yang bisa meramal masa depan, termasuk musibah atau kondisi darurat apa yang akan terjadi. Dengan kesepakatan bersama istri pengelolaan keuangan akan optimal untuk masa depan keluarga.

\section{PEMBAHASAN:}

Seperti yang sudah diketahui, dari hasil temuan lapangan wawancara ketiga pasang subyek dengan penjelasan analisis horizonalisasi, didapatkan pentingnya pola komunikasi baik yang dalam keluarga, kesamaan peran yang dapat menumbuhkan rasa nyaman dan juga keterbukaan diri terhadap pasangan. Makna dari komunikasi efektif yang bisa meningkatkan kualitas percakapan dan juga kelancarannya. Sebaliknya, komunikasi yang tidak efektif biasanya satu arah sehingga usaha yang selalu diupayakan dalam setiap keluarga adalah membangun komunikasi efektif dan dapat berdampak pada kepuasan perkawaninan. Kepuasan dalam perkawinan memang memegang peranan penting dalam keberlangsungan perkawinan itu sendiri. Perkawinan yang memuaskan 
juga ditandai dengan keintiman, komitmen, persahabatan, afeksi, pemuasan seksual, keamanan ekonomi, dan kesempatan untuk pertumbuhan emosional (Papalia, Olds \& Feldman, 2009). Apabila seseorang merasa puas terhadap perkawinan yang telah dijalani, maka ia beranggapan bahwa harapan, keinginan dan tujuan yang ingin dicapai pada saat ia menikah telah terpenuhi, baik sebagian ataupun seluruhnya. Hasil temuan lapangan juga menemukan konsep bahwa salah satu yang dapat mempengaruhi kepuasan pernikahan adalah adanya kesamaan peran dalam keluarga yang didalamnya terdapat kerjasama dalam peran domestik, berbagi peran dan tentunya istri mendapat dukungan penuh dari suami untuk menjalan perannya masing masing.

Dalam keluarga di Indonesia pada umumnya, orangtua atau lingkungan, secara langsung maupun tidak langsung telah menyosialisasikan peran anak laki-laki dan perempuannya secara berbeda. Anak laki-laki diminta membantu orang tua dalam hal-hal tertentu saja, bahkan seringkali diberi kebebasan untuk bermain dan tidak dibebani tanggung jawab tertentu. Anak perempuan sebaliknya diberi tanggung jawab untuk membantu pekerjaan yang menyangkut urusan rumah (membersihkan rumah, memasak, dan mencuci). Peran gender terbentuk melalui berbagai sistem nilai termasuk nilai-nilai adat, pendidikan, agama, politik, ekonomi, dan sebagainya. Sebagai hasil bentukan sosial, peran gender dapat berubahubah dalam waktu, kondisi, dan tempat yang berbeda sehingga peran laki-laki dan perempuan mungkin dapat dipertukarkan. Mengurus anak, mencari nafkah, mengerjakan pekerjaan rumah tangga (memasak, mencuci, dan lain-lain) adalah peran yang bisa dilakukan oleh laki-laki maupun perempuan.

Dengan demikian, pekerjaanpekerjaan tersebut bisa kita istilahkan sebagai peran gender. Jika peran gendermdianggap sebagai sesuatu yang bisa berubah dan bisa disesuaikan dengan kondisi yang dialami seseorang, maka tidak ada alasan lagi bagi kita untuk menganggap aneh seorang suami yang pekerjaan sehari-harinya memasak dan mengasuh anak-anaknya, sementara istrinya bekerja di luar rumah. Karena di lain waktu dan kondisi, ketika sang suami memilih bekerja di luar rumah dan istrinya memilih untuk melakukan tugas-tugas rumah tangga, juga bukan hal yang dianggap aneh. Konsep berikutnya yang ditemukan dilapangan adalah pentingnya keterbukaan diri terhadap kepuasan perkawinan dikarenakan dalam keterbukaan diri pasangan dapat meminimalisir konflik atau masalah seperti hal terkait keuangan dan pola asuh.

Melihat dalam kehidupan seharihari dimana wanita terlihat lebih terbuka secara konsisten dibandingkan pria, sehingga menimbulkan prasangka mengenai keterbukaan diri atau selfdisclosure bahwa self-disclosure itu lebih menunjukkan kepuasan pada wanita dibandingkan kepuasan pada pria. Namun, hal ini tidak didukung oleh literatur yang ada. Banyak penelitian yang menemukan bahwa self-disclosure berhubungan secara signifikan terhadap ke-puasan hubungan, baik untuk pria mau-pun wanita (Billeter, 2002). Namun memang terdapat perbedaan bagaimana self-disclosure tersebut dapat mempengaruhi kepuasan pada pria dan 
wanita dalam suatu hubungan.

Self-Disclosure disini dapat dipastikan mempengaruhi kepuasan perkawinan pasangan dapat lebih jujur dan terbuka mengenai dirinya dalam berkomunikasi dan dapat membuat pasangan lebih memahami mengenai perkawinan-nya. Mackey dan O'Brien (dalam Haseley, 2006) juga menyebutkan salah satu komponen kepuasan perkawinan adalah komunikasi dimana pasangan yang memiliki komunikasi yang positif dan dapat membicarakan berbagai persoalandengan pasangannya sehingga memiliki kepuasan perkawinan yang tinggi. Hal ini diperkuat oleh Halonen dan Santrock (1999) yang menyatakan pasangan yang mengalami kepuasan yang tinggi dalamperkawinannya memiliki rating tinggi dalam self-disclosure serta mengekspresi-kan cinta, dukungan dan perasaan.

\section{KESIMPULAN:}

A. Komunikasi yang efektif berperan dalam kepuasan perkawinan dalam komunikasi tersebut akan menimbulkan rasa nyaman sehingga menurut ke 3 pasangan, komunikasi yang baik merupakan salah satu cara yang efektif dalam memecahkan masalah, baik permasalahan terkait keuangan, keluarga, pola asuh anak dan seks.

B. Memahami perannya masing masing, kerjasama peran dalam keluarga merupakan syarat mutlak awal terjadinya pelaksanaan fungsi keluarga. Tugas keluarga akan terasa ringan apabila dikerjakan dengan tulus dan ikhlas disertai dengan perencanaan bersama antara suami-istri.

C. Adanya keterbukaan pasangan untuk mengenal dan memecahkan masalah yang muncul serta strategiyang digunakan untuk mendapatkan solusi terbaik.

D. Selain itu berbagi dengan keluarga baik dari segi finansial atau perhatian juga dapat menumbuhkan kebahagiaan dalam keluarga. Akibatnya, hal ini akan menimbulkan perasaan saling memiliki, keamanan, dan kenyamanan di dalam keluarga.

\section{REFERENSI:}

Billeter, C.B. 2002.An Exploration of Eight Dimensions of SelfDisclosure with Relationship

Satisfaction.Thesis.Virginia : Faculty of the Virginia Polytechnic Institute and State University

Djamarah, Syaiful Bahri. 2004. Pola Komunikasi Orang Tua \& Anak dalam Keluarga (Sebuah Perspektif Pendidikan Islam). Jakarta: Rineka Cipta

Gainau, M.B. (2009). Keterbukaan diri (self-disclosure) siswa dalam perspektif budaya dan implikasinya bagi konseling. Jurnal ilmiah Widya Warta, vol 33, No.1.

Halonen, J. S., Santrock, J. W. 1999.Psychology; Context and Aplications. 3rded.New York : McGraw-Hill.

Haseley, J.L. 2006 Marital satisfaction among newly married couples: Associations with religiosity and romantic attachment style.

Hidayah, N. Hadjam, N. 2006. Perbedaan Kepuasan 
Perkawinan antara Wanita yang Mengalami Infertilitas Primer dan Infertilitas Sekunder. Humanitas: Indonesian Psychological JournalVol. 3 No. 1 Januari 2006: $7-17$

Hurlock, E.B. 1991. Psikolgi Perkembangan Suatu Pendekatan Sepanjang Rentang Kehidupan. Jakarta : Penerbit Erlangga

Iskandar. Kedudukan Anak Tunggu tubang dalam Pewarisan Masyarakat Adat Suku Semendo di Kota Palembang (Tesis Magister Kenoktariatan). Universitas Diponegoro, Semarang, 2003.

Iskandar, dkk (2010). Faktor-faktor yang Mempengaruhi Kesejahteraan Keluarga. Sumatra Utara: Universitas Sumatra Utara. Jogiyanto (2004). Metode Penelitian Bisnis:

Lestari, Sri. (2012). Psikologi Keluarga: Penanaman Nilai dan Penanganan Konflik Dalam Keluarga. Jakarta: Kencana.

Muslimah, A.I. (2014) Kepuasan pernikahan ditinjau dari keterampilan komunikasi interpersonal. Jurnal Soul. Vol. 7 no. 2 hal. $14-21$

Papalia, dkk. 2008. Human Development (Psikologi Perkembangan).

Jakarta:Kencana Prenada Media Group

Praditama, M.R. "Sikap Masyarakat Terhadap Adat Tunggu tubang di Desa Pulau Panggung Kecamatan Semende Sarat Laut, Kabupaten Muara Enim". Jurnal Kultur Demokrasi, Vol. 1 No. 5 (2013): 4.

Setiawan, Robbi. Status Dan Peranan Tunggu tubang Serta Perubahannya Pada Masyarakat Semende Desa Muara Tenang Kecamatan Semende Darat Tengah Kabupaten Muara Enim (Skripsi Jurusan Sosiologi). Universitas Sriwijaya, Palembang, 2013.

Yoanita, Anastasia (2009). Peranan Perencanaan Keuangan Keluarga dalam Meningkatkan Kesejahteraan Keluarga. Skripsi. Bandung: Univesitas Katolik Parahyanga 